Piankova Oksana, $\mathrm{PhD}$ in Economics, Associate Professor Kyiv National University of Trade and Economics, Kiyv, Ukraine ORCID 0000-0002-7491-6543

Researcher ID N-7668-2016 Syerova Lyudmila, $\mathrm{PhD}$ in Economics, Associate Professor Kyiv National University of Trade and Economics, Kiyv, Ukraine ORCID 0000-0002-0739-1978

\title{
NATIONAL BRAND IN THE EXPORT STRATEGY OF UKRAINE
}

Ukraine's position as a reliable partner in the international sphere makes it an urgent issue of national brand development. The need to national brand development is also urgent as trade, political, cultural relations are deepening, and there is a need to maintain Ukraine's competitive position in the world market.

Keywords: national brand, branding, export, export strategy.

П'янкова Оксана, Серова Людмила. національний бренд в експортній стратегії Украӥни.

У статті доводиться важливість урахування чинника наџіонального бренду в умовах стрімкого розвитку Украйни як повноцінного партнера міжнародних економічних відносин, посилення позицій національної економіки на світовому ринку товарів та послуг. Позичіювання Украӥни як надійного партнера у міжнародних відносинах, прагнення подальшого поглиблення торговельних, політичних, культурних зв'язків, актуалізують необхідність подальшого дослідження окремих аспектів багатогранної наукової проблеми управління розвитком національного бренду краӥни-експортера. У статті визначено взаємозв'язок між експортною орієнтацією країни та силою національного бренду, акцентовано увагу на необхідності докладного дослідження факторів, щзо прямо чи опосередковано впливають на економіку України, конкурентну позиџію на світовому ринку.

Ключові слова: начіональний бренд, брендінг, експорт, експортна cтратегія. 
Relevance of research topic. The national brand is the identifier of the country's competitiveness in the world economy. The national brand emerged in domestic science in the twentieth century and became the most important determinant of the interaction formation between national economies in the twenty-first century.

The national brand development influences the development of a country, its economic status and political system, cultural and social spheres. Also, the national brand influences on the sphere of national security, geo-strategic priorities, integration aspirations.

The rapid development of Ukraine as a full-fledged partner of international economic relations, the need to strengthen national positions in the world market, actualize the issue of national brand development.

Formulation of the problem. Based on the achievements in theoretical developments in branding and practical aspects of Ukraine's development as an export-oriented country, it is appropriate to note that some aspects of the multifaceted scientific problem of the national brand management of an exporting country remain debatable and need further investigation. Particularly noteworthy is the dualistic approach to the primacy of the strong national brand influence on exporting country gains or, conversely, the formation of the country's brand on the basis of export performance.

Analysis of recent researches and publications. In the context of a national brand development in an evolutionary and revolutionary way, it is appropriate to focus on a complex revolutionary Ukrainian model, characterized as a qualitative shift.

The United States and European countries received certain consequences as a result of natural revolution. Our scientists are trying to investigate, analyze and adapt to Ukrainian realities these results.

PhilipKotler, David Gertner (2002) made significant contributions to the branding theory development. Veli Olins, Simon Anholt explored the development of national brands.

Simon Anholt says that country branding is a systematic process of reconciling a country's actions, behaviors, investments, innovations and communications, aimed at implementing a national security strategy (Anholt S., 2011).

Domestic scientists perceive the national brand in the world as a country identifying factor, a positioning tool, an informative source, a factor of a potential partner influencing, a product origin guarantee of the country, an integrative component of synergistic enhancement of competitive advantages.

Understanding the special role of the national brand in the development of an export-oriented economy contributes to establishing and maintaining the country's competitive position.

Presenting main material. We review the national brand development as a systematic process. This process is a set of mutually agreed components of the system, namely management. The process should be focused on building the identity and 
ensuring the spectrum of national security components and the competitive position of the exporting country. National brand is a source of competitive advantage, determines strategic orientation. The national brand forms and maintains relationships with partners through a combination of the intangible assets of the country (commercial, protective, competitive advantage in the market, cultural, coordinating, synergistic) and communication tool (information, providing, identifying, symbolic).

Brand Finance has been researching national brand development since 1996. The study consists of an analysis of strength and value of national brands.

Brand Finance National Brands has researched the most expensive national brands. According to the investigation, the United States is the traditional leader - the value of the brand increased in 2018 by $25 \%$ to $\$ 25899$ billion. China ranks second in the $\$ 10209$ billion ranking, Germany ranks third with a $28 \%$ increase in value to $\$ 5147$ billion. The top five are the UK (\$ 3750 billion) and Japan ( $\$ 3598$ billion). Ukraine's national brand ranks 60 th with a value of $\$ 84$ billion with a $23 \%$ over year growth.

Table 1

\section{Top 10 Countries with the Most Expensive National Brands by Brand Finance National Brands, 2017-2018}

\begin{tabular}{|c|c|c|c|c|c|c|c|}
\hline Nation Brand & \multicolumn{2}{|c|}{ Rank } & \multicolumn{2}{c|}{ Brand value (USD bn) 2018} & \% change & \multicolumn{2}{c|}{$\begin{array}{c}\text { National Brand } \\
\text { Strength }\end{array}$} \\
\hline & 2018 & 2017 & 2018 & 2017 & $2018 / 2017$ & 2018 & 2017 \\
\hline USA & 1 & 1 & 25,899 & 21,055 & 23 & AAA & AAA- \\
\hline China & 2 & 2 & 12,779 & 10,209 & 25 & AA & AA \\
\hline Germany & 3 & 3 & 5,147 & 4,021 & 28 & AAA & AAA- \\
\hline United & 4 & 5 & 3,750 & 3,129 & 20 & AAA & AAA \\
Kingdom & & & & & & & \\
\hline Japan & 5 & 4 & 3,598 & 3,439 & 5 & AAA- & AAA- \\
\hline France & 6 & 6 & 3,224 & 2,969 & 9 & AA+ & AA+ \\
\hline Canada & 7 & 7 & 2,224 & 2,056 & 8 & AAA- & AAA- \\
\hline Italy & 8 & 9 & 2,214 & 2,034 & 9 & AA- & A+ \\
\hline India & 9 & 8 & 2,159 & 2,046 & 5 & AA & AA \\
\hline South Korea & 10 & 10 & 2,001 & 1,845 & 8 & AA & AA \\
\hline Ukraine & 60 & 61 & 84 & 68 & 23 & A- & A- \\
\hline
\end{tabular}

Source: conducted by the authors on the basis of Brand Finance National Brands (https://brandfinance.com/images/upload/brand_finance_nation_brands_reports_2018).

The Future Brand Country Index, first published in 2014, aims to show the global perception of 75 different countries on a nationwide brand power rating. In addition to status, experience components include tourism potential, cultural and historical values, and quality of life. 
A study of the Global Top 75 rating positions shows that Japan, Norway and Switzerland remain the most successful national brands in the world. Ukraine's national brand ranks 74 out of 75 possible. The rating authors explain such a low result in 2014 and 2019 with military events, high riskiness of the Ukrainian economy, significant unpredictability of business development.

Table 2

Future Brand Country Index 2019 Global Top 75

\begin{tabular}{|l|l|l|l|l|}
\hline Ranking & $\begin{array}{c}\text { Point Change } \\
\text { from 2014 }\end{array}$ & \multicolumn{1}{|c|}{ Country } & $\begin{array}{c}\text { World Bank } \\
\text { Ranking 2019 }\end{array}$ & \multicolumn{1}{|c|}{ Region } \\
\hline 1 & $=$ & Japan & 3 & Asia Pacific \\
\hline 2 & +4 & Norway & 28 & Europe \\
\hline 3 & -1 & Switzerland & 20 & Europe \\
\hline 4 & $=$ & Sweden & 22 & Europe \\
\hline 5 & +8 & Finland & 42 & Europe \\
\hline 6 & -3 & Germany & 4 & Europe \\
\hline 7 & +2 & Denmark & 35 & Europe \\
\hline 8 & -3 & Canada & 10 & North America \\
\hline 9 & +1 & Austria & 27 & Europe \\
\hline 10 & - & Luxembourg & 73 & Europe \\
\hline 74 & $=$ & Ukraine & 60 & Europe \\
\hline
\end{tabular}

Source: conducted by the authors on the basis of Future Brand Country Index (https://www.futurebrand.com/uploads/FCI/FutureBrand-Country-Index-2019.pdf).

It is worth noting that the National Brand of Ukraine is just beginning its active development. Ukraine is difficult to perceive by the international community, on the one hand it is a high-risk warring country, on the other - «a logistical and mental bridge between west and east» (Sapry'kina M., 2015).

According to the CSR Development Center research (Sapry 'kina M., 2015), the world community perceives Ukraine as: a country with a rich culture, a country with significant economic potential, a country with corruption and political chaos, a country where it is dangerous to live. It should also be noted that experts believe that Ukraine has prospects for change.

Strengths include: people, natural resources, geographical location, opportunities, unique culture and democracy.

Most of the respondents identified weaknesses: corruption, political instability, poor economic development, inefficiency of government, poor popularization of Ukraine in the world.

Export impact investigation of national brand leaders helps to identify the presence of correlation between absolute export performance, balance the structure and value of the brand.

The analysis of Ukraine's export activity makes it possible to emphasize the imbalance of the export structure. According to the results of 2018, Ukraine is ranked 
46th in the world by export, 45th place - by goods export, is ranked 27 th by the share of agricultural raw materials in the total export structure, becomes 16 th in the world by foodstuffs export share, by 40th place in the industrial goods share in export, by results of 2017 Ukraine is 76th in the world in the high-tech goods share in industrial goods export.

Table 3

\section{Ukraine's Export, 2018}

\begin{tabular}{|l|c|c|l|}
\hline \multirow{2}{*}{ Indicator } & \multicolumn{2}{|c|}{ Ukraine } & \multirow{2}{*}{ Leaders } \\
\cline { 2 - 4 } & Rank & \multicolumn{2}{|c|}{ Value } \\
\hline Export of goods and services & 46 & 59117 million US dollars & $\begin{array}{l}\text { 1. China } \\
\text { 2. USA } \\
\text { 3. Germany }\end{array}$ \\
\hline Export of goods & 45 & 43345 million US dollars & $\begin{array}{l}\text { 1. China } \\
\text { 2. USA } \\
\text { 3. Germany }\end{array}$ \\
\hline $\begin{array}{l}\text { Export of agricultural raw } \\
\text { materials in the total export } \\
\text { structure, \% }\end{array}$ & 27 & & $\begin{array}{l}\text { 1.New Zealand } \\
\text { 2. Latvia } \\
\text { 3. Finland }\end{array}$ \\
\hline $\begin{array}{l}\text { Export of foodstuffs in the total } \\
\text { export structure, \% }\end{array}$ & 16 & $2 \%$ & $\begin{array}{l}\text { 1. Belize } \\
\text { 2. Cape Verde } \\
\text { 3. Saint Vincent and } \\
\text { the Grenada }\end{array}$ \\
\hline $\begin{array}{l}\text { Export of industrial goods in the } \\
\text { total export structure, \% }\end{array}$ & 40 & $39,1 \%$ & $\begin{array}{l}\text { 1. Hong Kong } \\
\text { 2. Andorra } \\
\text { 3. Israel }\end{array}$ \\
\hline
\end{tabular}

Source: conducted by the authors on the basis of Knoema (https://knoema.com/atlas).

It should be noted that Ukraine is not global development trends exception and is integrally active. Ukraine, like most countries in the world, needs to develop a strong national brand.

There is a close correlation between the export orientation of the country and the strength of the national brand in terms of origin and nature of manifestation and consequences. Today requires a detailed study of the factors that directly or indirectly affect Ukraine's economy, its competitive position in the world market.

It is advisable to consider the issues of national brand development in the context of strategic priorities of the country's development. One of the key areas is the export orientation of the economy.

The final goal of Ukraine's Export Strategy (Export Strategy of Ukraine's, 2017) is «science-intensive and innovative exports for sustainable development and success in world markets» through:

- creation of favorable conditions that stimulate trade and innovation for export diversification; 
- development of business and trade support services capable of enhancing enterprises competitiveness, including small and medium-sized businesses;

- strengthening the skills and competences of international enterprises, in particular small and medium-sized businesses.

Considering the problems of creation and formation of the national export brand of the country, it is appropriate to emphasize that Ukraine is identified in the world as supplying agricultural and food products. Existing and potential importing countries are increasingly focusing on co-operation in the agricultural sector, increasing purchases of agricultural raw materials, finished food and beverages.

Recognizing that Ukraine has a significant competitive advantage in the food market, the Government is taking the initiative in the context of the Export strategy implementation to create the Export Brand of Ukraine. According to the developers, it will become «a complete set of emotions, associations and characteristics of goods and services from Ukraine in the consumers' minds» (BRAND-BOOK), will help strengthen the position of the national brand.

Defining Ukraine as a «modern country and reliable trading partner that exports quality, innovative, technological and authentic products» (BRAND-BOOK) is a key slogan of export brand creating.

Formation of a positive image of Ukraine as an exporter of quality goods and services is the main goal of export brand creating.

Among the tasks: positioning Ukraine in the world as a reliable trading partner; stimulation of export growth; development of export-oriented industries; resources reduction to promote Ukrainian products to priority partners markets.

Depending on the sectoral affiliation, domestic manufacturers-exporters are offered a version of the «Trade with Ukraine» slogan adaptation in a more detailed version.

Table 4

\section{Adaptation of the exporting country brand name}

\begin{tabular}{|l|l|}
\hline The country's export brand & Trade with Ukraine \\
\hline Food \& Beverages & Taste with Ukraine \\
\hline Confectionary & Taste with Ukraine \\
\hline Information \& Communications Technology & Innovate with Ukraine \\
\hline Creative services & Create with Ukraine \\
\hline Toys & Create with Ukraine \\
\hline Perfumes \& Cosmetics & Create with Ukraine \\
\hline Furniture Industry & Create with Ukraine \\
\hline Machinery & Manufacture with Ukraine \\
\hline Electrical Machinery & Manufacture with Ukraine \\
\hline Aerospace: Spare parts \& Components & Rocket with Ukraine \\
\hline Aircraft Maintenance & Fly with Ukraine \\
\hline
\end{tabular}

Source: conducted by the authors on the basis of Export Promotion Office materials. 
The work of the Export Promotion Office continues. The Office makes practical efforts to assist experienced and potential exporters. Particularly important is the great educational work, export consulting, exhibition activities, information and analytical support, organization of trade missions, etc.

Conclusion. Undoubtedly, a strong export-oriented economy is capable of forming a strong national brand. It is advisable to review the structure of domestic exports in favor of knowledge-intensive and innovative in the context of the Ukraine's Export Strategy implementation. The new export structure will create the preconditions for strengthening the position of Ukraine's national brand as a reliable strategic partner among the developed countries of the world.

\section{REFERENCES}

1. Anholt S. (2011) Beyond the nation brand: The role of image and identity in international relations. In: Journal of Public Diplomacy, Vol. 2, No. 1, 6-12.

2. Brand Finance National Brands. Retrieved from http://brandfinance.com/ images/upload/brand_finance_nation_brands_reports_2018

3. Brend-buk eksportnogo brenda Ukrayiny (2018) Ofis z prosuvannya eksportu. Retrieved from https://epo.org.ua/

4. Export Promotion Office. Retrieved from https://epo.org.ua/

5. Export Strategy of Ukraine's (2017). Kyiv: The International Trade Centre

6. FutureBrand Country Index. Global Top 75 (2019). Retrieved from https://futurebrand.com/uploads/FCI/FutureBrand-Country-Index-2019.pdf

7. Kotler Ph., Gertner D. (2002) Country as brand, product, and beyond: A place marketing and brand management perspective. In: Journal of Brand Management, Vol. 9, No. 4-5, 249-261

8. Olins W. (2002) Branding the nation - the historical context. In: Journal of Brand Management, Vol. 9, No. 4-5, 241-248.

9. Sapry`kina M. (2015) Spry`jnyattya Ukrayiny v krayini i sviti. Kyiv: Centr «Rozvytku KSV»

10. World Atlas Data. Retrieved from https://knoema.com/atlas 